\title{
APPLYING BLENDED LEARNING IN HIGHER EDUCATION IN AMBON, INDONESIA: DESCRIPTIVE REPORT FROM GRAMMAR IN WRITTEN DISCOURSE CLASS
}

\author{
Helena Magdalena Rijoly \\ English Department, Pattimura University, Ambon - Maluku Indonesia \\ rijolyhelena@yahoo.co.uk
}

\begin{abstract}
This paper is an account on the application of Blended Learning in Higher Education setting in Ambon, Indonesia. The Blended Learning was applied to the Grammar in Written Discourse Class in English Study Program of Faculty of Teachers' Training Unpatti. The Blended Learning process was supported by the use of three online platforms: Google Classroom, Quizziz and Kahoot. The main purposes of this paper are: to describe the process of applying the blended Learning from planning, preparation, application and evaluation, to describe the challenges of applying the Blended learning for the Lecturer, to describe the challenges of using the Blended learning for the students and to describe the lesson learned and successes from the application of Blended Learning.
\end{abstract}

Keywords: Blended Learning, e-learning, Flipped Classroom, In-Class and Off-Class Learning, Google Classroom, Quizziz, Kahoot

\section{Introduction}

Every new student gathering and inductions at the university this year has a session on education in 4.0 industrial era. Students are urged to develop the skills and to change their mindset to face the already emerging 4.0 industrial era. The 4.0 Industry is a collective term used around the world to describe the emergence of the fourth industrial revolution. The industrial revolution evolves from steam and water power to electricity and assembly line to computerization and now to a cyber physical system (Marr, 2016). This means that new technologies and its usage have highly impacted all disciplines in life. Indonesian President, Joko Widodo, stated in April 2018 Industrial Summit that 4.0 Industry is now transforming the world 'characterized by the digital manufacturing that adopts computers and automation, alongside smart and autonomous systems fuelled by data and machine learning' (Expat, 2019). The new revolution adds a new challenge to education sectors such as the higher education level or universities to be able to prepare students to face the new demands in the work field. Therefore, education sectors, most importantly the higher education institutions, must "take full advantage of the opportunity created by advanced technology" because we need a similar revolution in education industry to meet the demands of the workforce and at the same time "ensuring the best possible student experience" (Jisc, 2019). 
One of the trademarks of 4.0 Industry is the use of technology. However, technology use and integration are only half of what the industry demands. The revolution saw the rise of AI technology and smart devices that slowly "took over" our daily life. We saw the rise and popularity of self-driving car, drones, smart(er) phones, virtual assistants, translation software on the go and so on (Schwab, 2016). The technology accommodates for efficiency and pleasure in our life but at the same time it presented the challenge to the group of people with limited access to rapid technology development. Therefore, human as users of technology must not be lulled by the convenience of AI around us and instead actively pursuing ways to make the AI work for us and not the other way around.

4.0 Industry in Education sectors presented both challenges and benefits/ opportunities. Internet and AI technology give new learning sources. Information and learning are on the fingertips of every students with smart phones. The developments and access to websites, online learning platform and educational apps means that learning is no longer limited within the walls of schools or the library or to how many heavy books you can carry. Faster internet connection allows students to tapped into their preferred learning style: through video, games, interactive sessions, hands-on-activity etc (Karnad, 2014). However, the users of technology are currently not winning against the technology. Recent news in Indonesia reported the abuse of technology use in children as young as toddlers where parents substitute game time with screen time. Many news articles reported psychological and physical damaged to the so-called Generation $\mathrm{Z}$ such as social disassociation, addiction, obesity, cancer etc (Safira, 2019). These phenomena occur due to the lack of guidance and education on safe technology and internet use (Trisna, 2019). Parents, teachers and adults around these children are not able to provide this safeguarding because they themselves are caught up uneducated on this matter in the whirlwind rise of the technology.

Therefore, education sector and education institute must invest their time and energy to educate the technology user, in this case the educators and the students. The way to do this is to start taking control on the use of technology. Educators need to educate themselves on the new learning platform and instead of comparing and reminiscing the 'old-times', need to work towards leveraging the use of technology in their respective classroom. Educators need to teach not only what and how to use the technology but also nurturing a healthy, effective and ethical technology use in their students' mind.

\section{Pds (Penugasan Dosen Di Sekolah) Program}

Penugasan Dosen Di Sekolah or Lecturer Assignment at School is a program by the directorate general of learning and studentship in the Research, Technology and Higher Education Ministry of Indonesia. The program is directed to the Faculty of Teachers Training and aims to bridge the campus and classroom to mainstream the higher education learning with the demands and needs of the school. Lecturers at faculty of teachers' training are paired up with the partner school and must experience first-hand the situation and condition at school and contribute to the learning process. This process hoped to improve the cooperation 
between campus and partner schools though sharing of information and new innovation. On the long run, it is hoped that it will produce a better teacher education content which in turn produce better teachers and later these teachers will produce a better future generation (FKIP-UNPATTI, 2018).

The year of 2019 marks the follow up program or the $2^{\text {nd }}$ phase program for $1^{\text {st }}$ batch of PDS where lecturers are asked to implement their learning experience in partner school during the $1^{\text {st }}$ phase program. In the previous phase, the PDS program for English Subject was conducted between English Department, FKIPUnpatti represented by the lecturer, Helena. M. Rijoly, S.Pd., MA ELT at the partner school SMP N 6 Ambon. An innovative approach was conducted through the use of Instagram as speaking skill assessment tool and students' interaction and engagement strategy (Rijoly \& Tuhumury, 2019). For this $2^{\text {nd }}$ phase program, the lecturer is placed in their respective University departments. The $2^{\text {nd }}$ phase is conducted in Grammar in Written Discourse Class as the pilot project.

Grammar in Written Discourse class is the first of 4 class grammar class series. It is offered to the $1^{\text {st }}$ semester students. Grammar in written discourse is an important class because it is a prerequisite to the grammar classes and writing classes in the next semester. The course is designed to build basic grammar knowledge, bridging the existing knowledge and the knowledge and skill needed to achieve the competencies. This is important because the knowledge of grammar and the skill to use it correctly will highly benefit their learning of other skills during their study at English department.

There are 3 parallel Grammar in Written Discourse classes in this semester. The PDS program Pilot class is conducted in Class A. Class A was chosen because it is the class where PDS participants teach. The teaching of Grammar in Written Discourse in class A was conducted in a Blended Learning Model with the integration of technology such as Google Classroom, Kahoot!, Quizziz and WhatApp.

This paper is a descriptive report on the effort to apply blended learning where technology was integrated and taught alongside the teaching of the language. The paper strives to present four objectives:

1) to describe the process of applying the blended Learning from planning, preparation, application and evaluation,

2) to describe the challenges of applying the Blended learning for the Lecturer,

3) to describe the challenges of using the Blended learning for the students

4) to describe the lesson learned and successes from the application of Blended Learning

\section{Blended Learning In Grammar In Written Discourse Class}

Blended learning is a hybrid classroom which blends face-to-face meeting with online activity. Sloan Consortium or currently known as Online Learning Consortium defined hybrid courses as those that "integrate online with traditional face-to-face class activities in a planned, pedagogically valuable manner" (Teach Thought Staff, 2018). Therefore, technology use is not simply as a supplement but also to transform and improve the learning process. Uploading materials online to 
be accessed by students is not a blended learning. It is merely a technology integration (Jonson, 2014). Blended learning is a learning model where online education materials and opportunities for online interaction is combined with faceto-face classroom methods where access to information is also accompanied with online discussion and collaborative work. Therefore, it is not only teacher to student interaction but also student to student interaction.

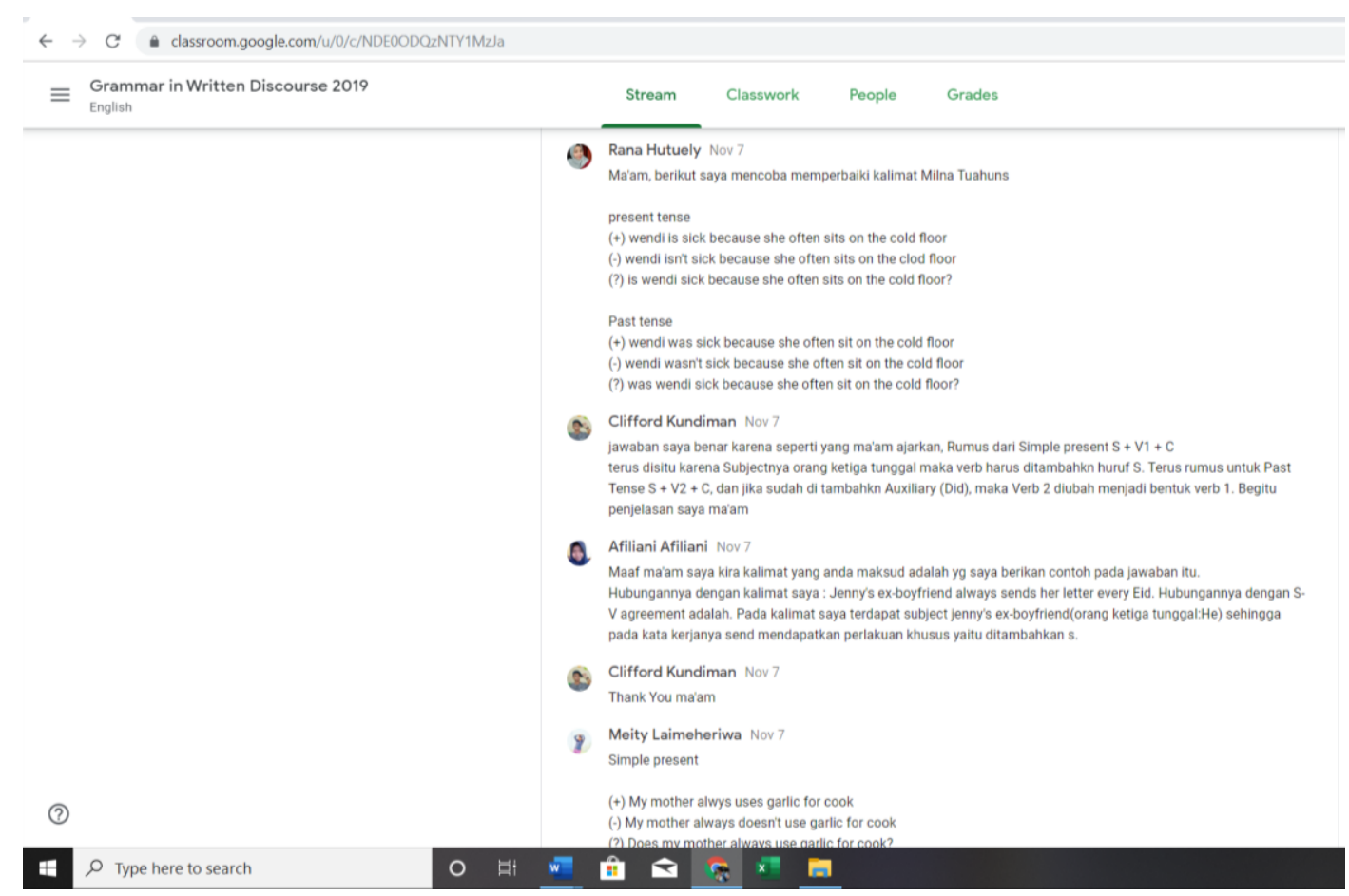

Figure 1 Online discussion sample: Teacher-Student, Student-Student

There are 49 registered students in Grammar in Written Discourse class however, only 45 students are active in the classroom as informed by the attendance. In grammar in written discourse class, blended learning was conducted with the support of several online platform: Google Classroom, Quizziz, Kahoot! And WhatsApp group. Google classroom was used as the online classroom platform. Quizziz is used as an online assessment tool. Kahoot! was used for fun interactive classroom assessment and activity. Meanwhile WhatsApp group was used for faster information and communication line between students and lecturer. The combination of all these platforms allow lecturer to continue the learning even in an off-class circumstances. It has proven to be particularly useful during the event of 2019 Ambon Earthquakes from Sept 26 to October $10^{\text {th }}$ where classes were cancelled as an earthquake emergency response policy.

This paper is designed to give the reader an overall insight to the application process. It will describe the planning, preparation, application and evaluation phases and present the lesson learned through the challenges and successes.

\section{Blended Learning Application}




\section{Blended Learning: Preparation and Planning Phase}

The practice of Blended learning model has been tried and tested by the lecturer in the last 2 years of her classroom teaching. She has tried several different online platforms from Facebook and emails to Edmodo and Moodle. She has discussed with the previous students and has had several valuable feedbacks which allows her to decide which online platform and what strategy to use. Some of the feedback are:

- Internet access and reliability are very difficult to obtain by all the students. The mobile data package is deemed too expensive by majority ofjhsdf the students. Meanwhile campus Wi-Fi connection is too slow and sometimes cannot be accessed

- Students are not used to participate in an online setting. Their online activities focus more on social media, communication - Information and to look for academic articles to support their classroom learning.

Therefore, students' mindset and habit in using technology for learning were not developed to the standard that will allow the blended learning to run effectively and efficiently. It was also observed that students' digital literacy skills are also very low in most of the Digital Literacy components (UNESCO, 2018). The students' low digital literacy skills combined with the poor facilities and infrastructure are the biggest challenge for a technology enhanced language learning or a blended learning model (Rijoly H. M., 2017).

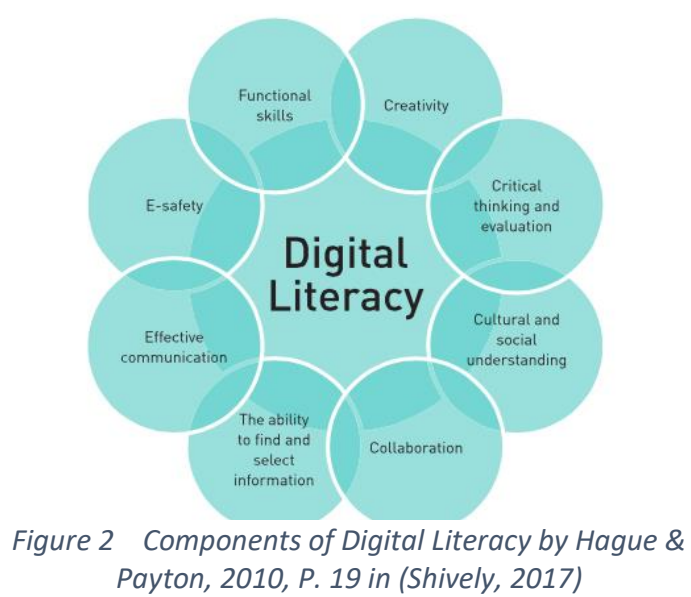

Therefore, before

embarking blended learning application, a baseline data questionnaire was distributed to obtain the demographic situation of the students. The questionnaire was a 19 items questions. Out of the 45 active students, 41 students completed and submitted the questionnaire. The result shows the following:

- On gadget use: $90.2 \%$ of the students own their own desktop computer. $65.9 \%$ of the students own their own laptop where they can bring to campus anytime it is needed. $100 \%$ of the students own their own handphone (smartphones) with top leading brands are Samsung and Oppo. 
- The questionnaire results inform that ALL the smartphones can be and are used to connect to internet, to browse and to do other online activities.

- User connectivity: Almost half of the students (46\%) admits to go online in the late afternoon or evening. $26.8 \%$ admits to stay connected all day long.
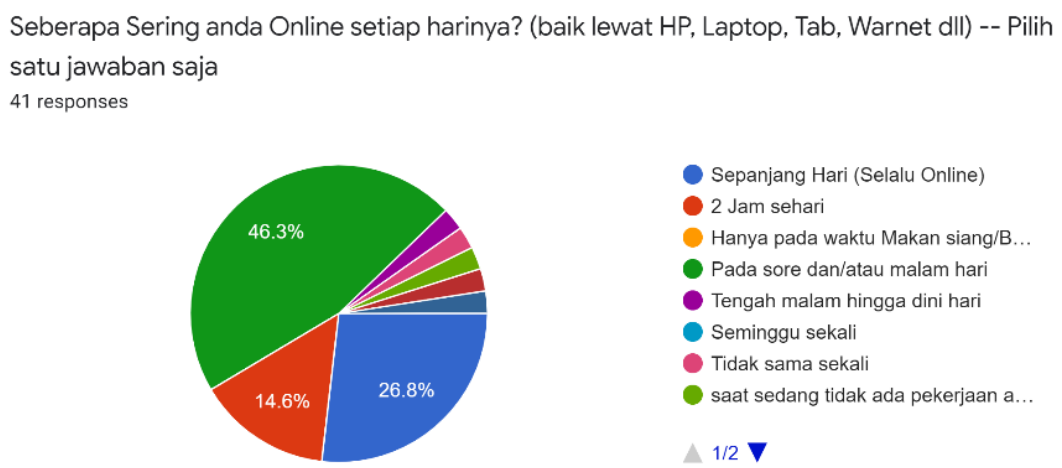

Sepanjang Hari (Selalu Online)

2 Jam sehari

Hanya pada waktu Makan siang/B

Pada sore dan/atau malam hari

Tengah malam hingga dini hari

Seminggu sekali

Tidak sama sekali

saat sedang tidak ada pekerjaan a...

Figure 3 Online Duration in a day

- User Online Habit: When they are online, Majority of the respondents listed that they use the internet for WhatsApp (70.7\%), Facebook (61\%), Instagram (56.1\%), Email/Gmail (26.8\%)

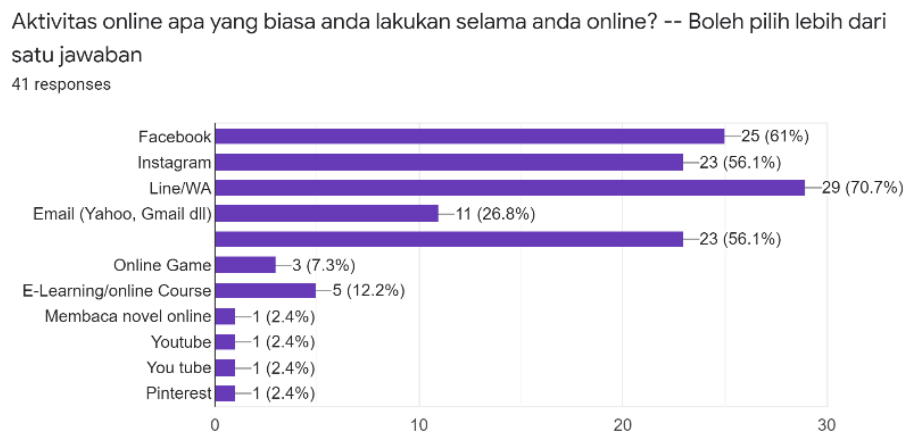

\section{Figure 4 Online User Habit}

- Respondent for 2019 Grammar in Written Discourse class described their internet connection as Good - less problems in connection where the connection is generally fast and stable with only few down time (53.7\%). Good Enough (24.4) and Very Good (19.5\%). 
Menurut anda bagaimana kualitas koneksi internet yang biasa anda gunakan tadi 41 responses

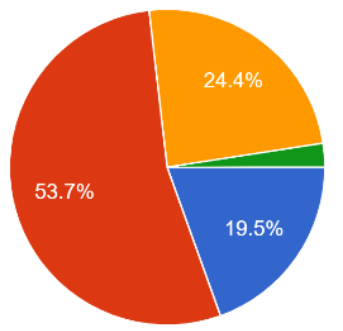

Sangat baik - Sama sekali tidak ada masalah. selalu lancar dan koneksinya cepat dan stabil. Saya..

Baik - jarang sekali bermasalah. koneksi cepat dan stabil. Namun saya pernah mengalami ada bebe...

Cukup Baik - Walau ada gangguan tiap hari namun secara umum dap..

Buruk - Koneksinya lambat dan tidak stabil. Sangat tidak bisa diandalka..

\section{Figure 5 Internet Connectivity}

- Respondent listed IDR 50,000 - IDR 150,000 as the total cost for online need. All of the respondents are not working yet. $90.2 \%$ of the respondents receive this amount from their parents. Meanwhile 2 of the majority livelihoods of their family are Farmer/Fisherman (34.1\%) and Government Officials $(26.8 \%)$
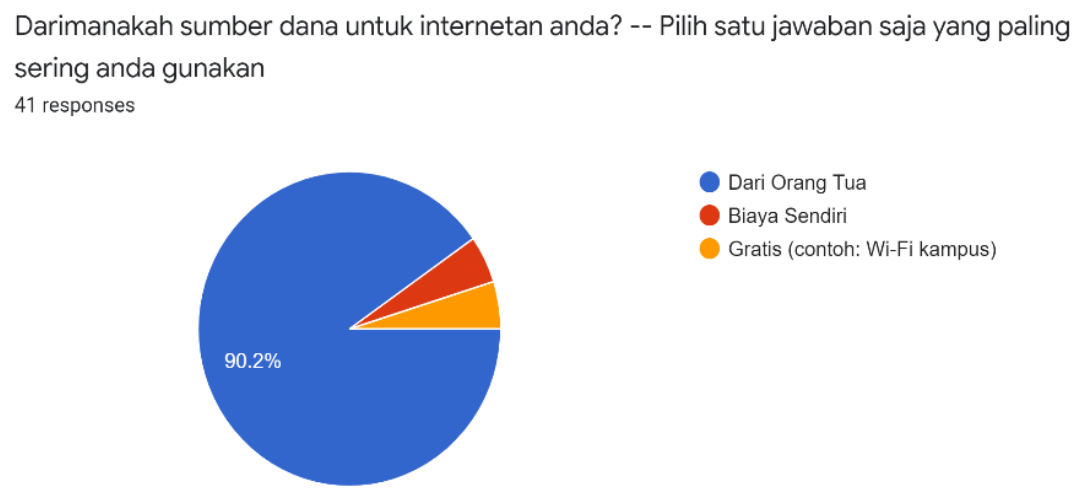

Figure 6 Financial source for Internet Cost

The questionnaire results highlight several important considerations such as: 1) Access to internet and to gadgets for this batch of students are suitable for the use of technology in the classroom, 2) students prefer to use social media type of platform, 3) There are many other places that students can go and use computer and to connect to internet with a reasonable and even cheap price. Based on that findings and the spirit of trying new platforms to see which suited the students and lecturer preference and circumstances, Blended Learning for this class was designed by using Google Classroom, Quizziz, Kahoot! And WhatsApp group.

Google classroom is chosen because of its user-friendly interface and imbedded interaction with Gmail that all students already have. Students have had their Gmail account as a requirement in the new SIAKAD (University Online Academic) Platform. Kahoot! is a fun online interactive platform where learning and assessment can be presented as an online real-time or off-class game. Quizziz 
is chosen because the class needed a more concise and compact assessment platform where the result of the submitted quiz can be easily analysed. Quizziz and Kahoot! can be introduced because the online activity can easily be connected to google classroom. Since the students have their Google Account already, it is a one click step to create their Quizziz and Kahoot! account.

The preparation was completed in more or less 1 week worth of work. It is fortunate that the Grammar in Written Discourse class has an official Textbook produced through previous faculty funding. Thus, the content lessons were breakdown to several meetings according to the syllabus. Teaching plans are also revamped to accommodate lesson learned from last year class as well as incorporating new development and up-to-date news. There were many works to be done in preparation phase such as:

- Prepare teaching plans per meetings, designed online post, online task, face-to-face classroom activities and task. Making sure that the online activities are connected, support and elaborate the learning.

- Create back-up plans in case of unforeseen events

- Consult Ambon teaching schedule with PSDKU teaching schedule

- Setting up Online Classroom at Google Classroom. Then upload and scheduled upload the lesson, announcements, assignments, online quizzes etc.

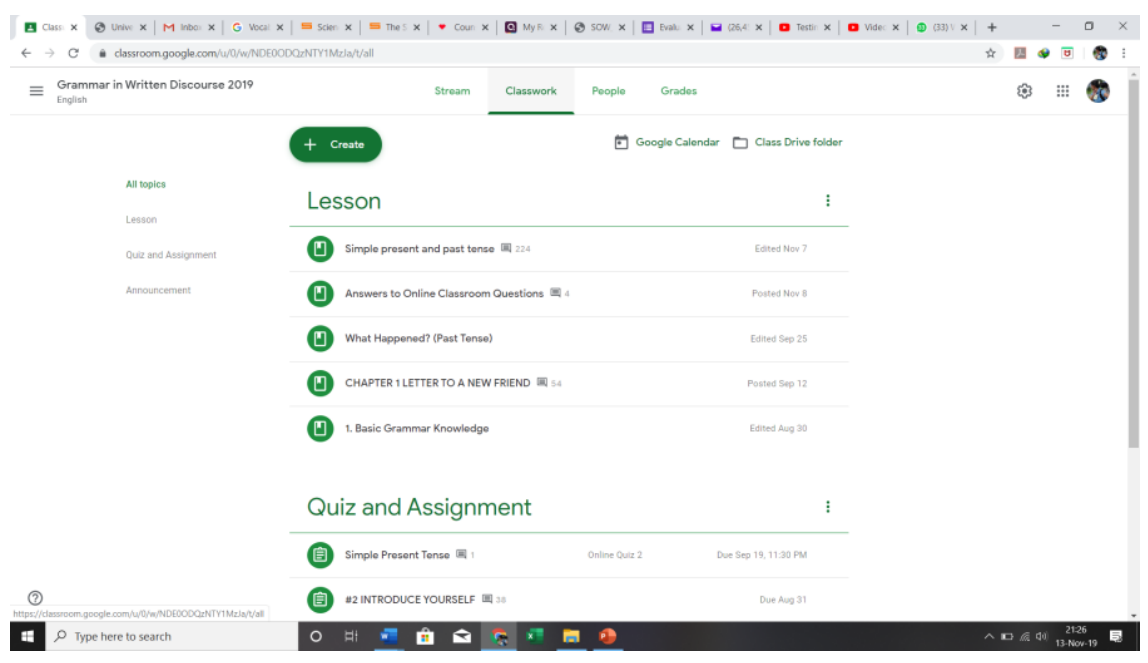

Figure 7 GIWD on Google Classroom

- Set up Account for Quizziz and Kahoot!

- Design online quizzes and tests.

- Pilot test the online platform to several students and ironed out the kinks based on the feedback.

- Plan a tech support meeting and introduction which will be conducted during the $1^{\text {st }}$ meeting learning contract meeting. 


\section{Blended Learning: Application}

Blended learning was applied to 11 meetings out of the total 16 meetings in a semester, from 22 August - 31 October 2019. The Blended Learning application activities are as follows:

- Meeting 1: 22 August 2019 (Classroom Meeting):

This was the first meeting and, on this meeting, lecturer introduced the course and together with the students discussed the learning contracts. Lecturer also informed the class about PDS program and that the class will be using Blended Learning Models. The Platforms are introduced and explained. The class ended with a task for the students to create their online platforms accounts and to try and familiarized themselves with the online use. They were asked to access Google Classroom and to complete the online task set for them. This is a strategy for lecturer to monitor whether the students have the accessed and perhaps identify problems to be discussed in the next meeting. They were given 1 week and were asked to help each other and to follow the guidelines that the lecturer provided.

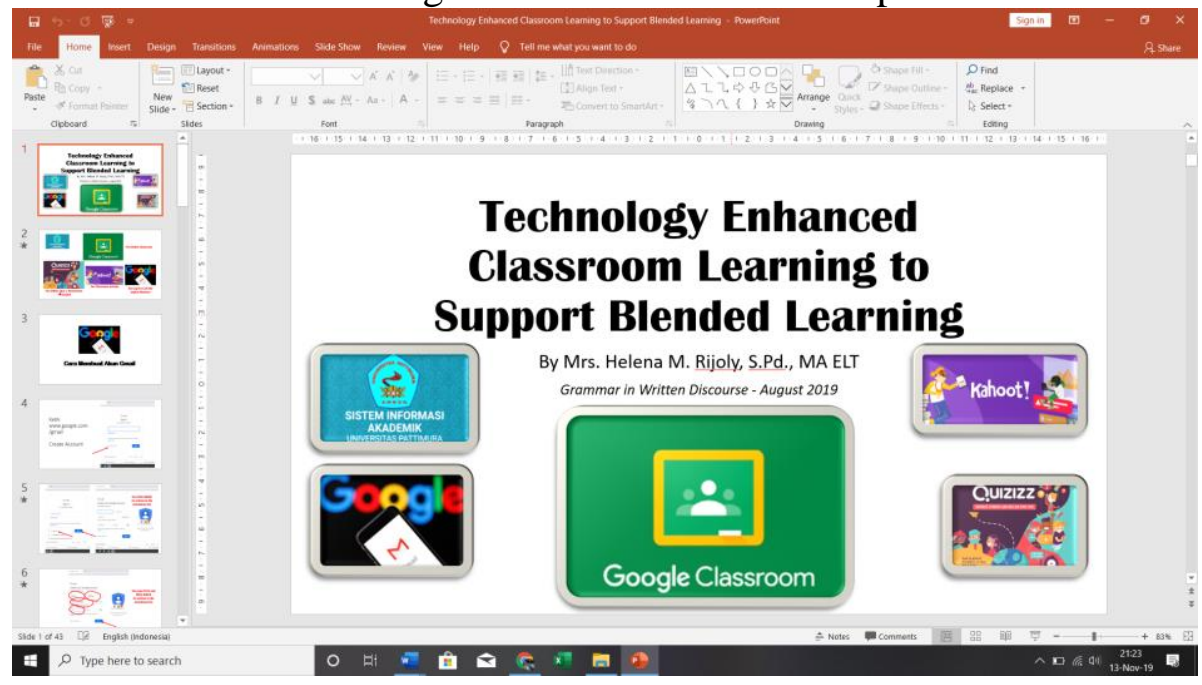

Figure 8 Step-by-step Guidelines to Online Platforms use in GIWD 2019 Class

- Meeting 2: 29 August 2019 (Classroom Meeting)

This meeting was dedicated to review the online platform use and to discuss students' problems. Lecturer simulated Google Classroom and Quizziz use together with the students and try-out the Kahoot! with the materials from Learning Contract. Class ended with students being given the task to access Google Classroom for lessons and discussions and to complete an online quiz at the end.

- Meeting 3: 30 August 2019 (Online Activity)

Matriculation meeting where students learned basic sentence structure, parts of speech overview and other grammatical concepts. Students are given 
materials in google classroom which includes handouts, links to Youtube and others online resources. This online class was designed to supplement with the Matriculation Session for the New Students Induction Programs. The induction programs were a 3 days matriculation session for Grammar, Writing and Reading.

- Meeting 4: 4 September 2019 (Online Activity)

Students are asked to access Google Classroom and learn about the $1^{\text {st }}$ topic. Introducing of self and others and grammar focus simple present tense. At the end of the online session, students are asked to complete a quiz on Quizziz.

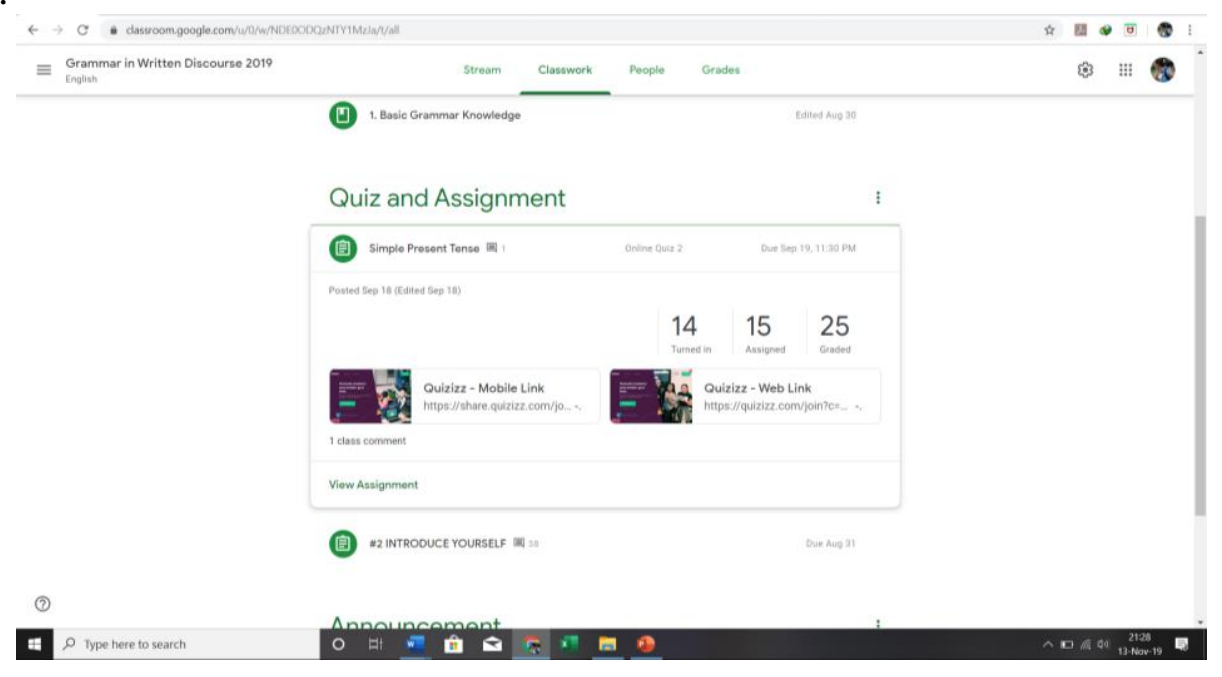

\section{Figure 9 Online Quiz using Quizziz}

- Meeting 5: 5 September 2019 (Classroom Meeting)

Having an online class beforehand enable the class delved directly on the practice on introducing self and others where instead of spending time on lengthy explanation. During this class meeting, lecturer was able to discuss the error in grammar and pronunciation.

- Meeting 6: 12 September 2019 (Online Activity)

This class meeting was coincided with 'Kuliah Umum' held by the Faculty as part of the new student's intake induction. Therefore, the classroom meeting is postponed and replaced with an online class. Through Google Classroom and supported by the Buku Ajar (textbook) students are able to learn grammatical application of talking about self. They are required to learn the lesson and to post their work on Google Classroom. The works were given feedback and commented by the lecturer and also peers.

- Meeting 7: 19 September 2019 (Classroom Meeting)

In this meeting, lecturer was able to embark on a deeper error analysis discussion with the students. This was not something that this course can achieve in the previous 2 classes 
- Meeting 8: 20 September 2019 (Online Activity)

Students are given task to learn the materials through google classroom in preparation for the next class.

- Meeting 9: 26 September $2019 \rightarrow$ Class Cancelled due to Earthquake.

The classes were suspended until 10 October 2019. Due to the fact that students are evacuating which make situation and condition are not favourable for learning. Students are asked to continue learning and to complete the online quiz in preparation for MidTerm Test.

- Meeting 9: 17 October 2019 (MID Term Test - Classroom Meeting)

The lecturer was away on teaching trip to Aru Islands but the MidTerm Test meeting was still conducted. It was administered by a teaching assistant.

- Meeting 10: 24 October 2019 (MID Term Test - Classroom Meeting)

The lecturer was still away on teaching trip to Aru Islands. This meeting was dedicated for follow-up test for students who didn't get to follow the test the previous week due to earthquake evacuation, sickness etc. It was administered by a teaching assistant.

- Meeting 11:31 October 2019 (Classroom Meeting)

This is the first-time lecturer was able to have a classroom meeting with the students after the earthquake events. In this meeting, lecturer assessed and further discuss the topic of Simple Past Tense as well as discussing the answer and result from the mid-term test. This class used Kahoot! and also apply the chain story techniques for This class meeting was recorded for the teaching video.

\section{1) Blended Learning: Evaluation}

So far with the blending of classroom meeting and online activity, students were able to have more learning time. The class have managed to get 2 quiz scores through the Quizziz Classroom, 2 real-time online classroom interactive assessment through Kahoot! and 1 Mid-term Test score. Classroom participation increased with all students participating in Online and classroom meetings. Students are also much more satisfied with learning and eager to come to class.

A simple online feedback form was distributed to the students to evaluate the use of blended learning. Students were asked what is their opinion on the technology use in the classroom. All of their responses were positive and encouraging. Below are the sample feedbacks: 


\section{Students' Original Feedback in Bahasa Students' Feedback translated Indonesia}

\begin{tabular}{|c|c|}
\hline $\begin{array}{l}\text { "Saya sangat senang, karena dalam } \\
\text { mata kuliah ini kami menggunakan } \\
\text { kecanggihan teknologi yang ada, } \\
\text { contohnya Goggle class room dan } \\
\text { membutuhkan pulsa internet, dimana } \\
\text { ketika kami tidak berlajar di kampus } \\
\text { tapi kami punya kelas online } \\
\text { menggunakan android yang kami } \\
\text { gunakan sehingga waktu belajar kami } \\
\text { tidak terbuang percuma karena tidak } \\
\text { ada tatap muka di kelas antara } \\
\text { mahasiswa dan dosen" }\end{array}$ & $\begin{array}{l}\text { am very happy because this class } \\
\text { uses advance technology such as } \\
\text { Google Classroom which requires us } \\
\text { to use internet (data Package). We not } \\
\text { only learn in campus but we also have } \\
\text { online class where we can access with } \\
\text { android gadget, therefore our time is } \\
\text { not wasted just because there is no } \\
\text { classroom meeting between students } \\
\text { and lecturer. }\end{array}$ \\
\hline $\begin{array}{l}\text { "Sangat bagus, saya yang awalnya } \\
\text { tidak tahu kahoot.it jadi tahu ehehe, } \\
\text { langkah ini pun bisa menjadi motivasi } \\
\text { bagi murid agar mau terus belajar } \\
\text { karena teknologi sudah terlalu canggih } \\
\text { untuk hanya dipakai main-main." }\end{array}$ & $\begin{array}{l}\text { Very good. In the beginning I didn't } \\
\text { know what is Kahoot! now I know } \\
\text { about it. This step is a motivation to } \\
\text { us students to keep on learning } \\
\text { because technology too advanced } \\
\text { now to be used only for playing. }\end{array}$ \\
\hline $\begin{array}{l}\text { "Sangat membantu dan sangat } \\
\text { menyenangkan karena lebih efisien } \\
\text { terhadap waktu. Misalnya, jika ma'am } \\
\text { memiliki tugas mengejara di tempat } \\
\text { lain ma'am bisa mengirimkan materi } \\
\text { lewat google classroom atau melatih } \\
\text { pemahaman mahasiswa dengan } \\
\text { menggunakan kahoot." }\end{array}$ & $\begin{array}{l}\text { Very helpful and fun because it is } \\
\text { much more efficient with time. For } \\
\text { example, when the lecturer was away } \\
\text { on teaching trip to other place, the } \\
\text { lecturer can post lesson/materials } \\
\text { through google classroom or she can } \\
\text { help student to practice their } \\
\text { understanding through kahoot. }\end{array}$ \\
\hline $\begin{array}{l}\text { Terlepas dari berbagai masalah seperti } \\
\text { koneksi yang tidak dapat diprediksi, } \\
\text { saya menyukai penggunaan teknologi } \\
\text { dalam perkuliahan ini. }\end{array}$ & $\begin{array}{l}\text { Despite various unpredictability in } \\
\text { connectivity, I enjoy the technology } \\
\text { use in this class. }\end{array}$ \\
\hline
\end{tabular}

All students gave similar positive and encouraging responses when asked about their opinion on the use of Google Classroom, Kahoot! and Quizziz.

\section{Challenges Of Applying Blended Learning For Lecturer}


There are several challenges that can be reported from the application of blended learning in Grammar in Written Discourse Class. One of the biggest challenges is Time. Setting up a blended learning requires the lecturer to commit ample time to revised the lesson, update the materials, design online and classroom activity that supported and complement each other in a seamless flow from one meeting to the other. This requires time to carefully plan each activity. However, as a lecturer and government officials there are many other responsibilities that make you unable to devote ample time for this. In this case, Seminar Proposal and Thesis Defend Session and consultation took up longer time than usual to speed up the process for the near drop-outs students. BKD and SKP revision work also took up time. However, this class has been using Blended learning for 2 years already and a material and quiz bank were available for use. The time was mostly spent to design the online platforms and the activity as well as designing tech support package and tutorial guidelines for all the online platforms.

The second challenge is the unforeseen event in this case earthquake. The earthquake that hit Ambon Island was severe and heightened by tsunami rumour. This prompted massive evacuation to higher grounds and other safe places including evacuating outside of Ambon Island. The university issued a campus activity cancelation and from Sept 26 - Oct 10, Campus activity was ceased.

Internet connectivity was not a problem this time for the lecturer because blended learning preparation and application uses IndiHome fast internet connectivity provided by the English Department during work hours and IndiHome connection at home during non-working hours or when at home. However, for other teachers or lecturer who do not have access to fast and reliable connection, this can be a major problem due to the nature of blended learning in using technology and internet.

\section{Challenges Of Using Blended Learning For Students}

Students were asked to give their feedback on the challenges they faced in applying blended learning and using the online platforms. They were asked on their feedback on the use of Blended Learning and technology as well as their separate feedback on the use of Google Classroom, Kahoot! and Quizziz. As mentioned above, all student gave positive and encouraging feedbacks. Some students mentioned come challenges as minor. Therefore, upon further discussion, the study can highlight 2 challenges. One is the Internet connection and Access to Internet. Recently, internet connection is getting better. It is much steadier and more reliable with $4 \mathrm{G}$ connectivity. This because Telkomsel as the sole communication provider have increased their coverage and connectivity. Most students also have IndiHome Internet connection at home where for their study. Most of them formed a study group and went to friend's house with IndiHome and use the connectivity for an hour or two. The University have yet to provide reliable internet connection to students to support blended learning or technology enhanced learning model.

Next challenge is the internet access. Despite the fact that connectivity is improving recently (Rahman, 2019) as well as all students have smartphones, 
access to internet is still a privilege. You can have the most advance technology on your phones but without Wi-Fi or Internet Package Data, you cannot utilize that smartphones for blended learning. The price for Mobile data for Eastern Indonesia, in this case Ambon, remain the highest (Prihadi, 2017). Due to this challenge, during classroom Real-Time Interactive Online learning through Kahoot! some students were working in groups. Those with no internet data package, joined their friends who have or write down their answers on a piece of paper. This is not ideal but at least it helps to get students to actively participate.

Although not reported by the students, it was observed that some students were having problems accessing and interacting online due to their lack of experience and skills in technology use. This is proven by the fact that some students made more than one account because they got locked out from their previous account due to them forgetting user name and password. Some other minor challenge was students posting their comments or work not in the thread it provided but to the wall thread which caused their assessment score not recorded. This challenge was resolved by assigning a tech-savvy student to aid the identified struggling students.

The last challenge that was not reported by observed was students' unfamiliarity with independent work mindset. Students are still not able to study independently and autonomously. Perhaps because our education system thus far does not instil this autonomous and independent learning before. Students tend to complete the task during the last minutes and some of them suffer the consequences of inadequate answers or failing to upload due to bad connection etc. They are also only stick to the prompt question and not embarking on to elaborate the learning themselves.

\section{Lesson Learned And Success From The Application Of Blended Learning}

Blended learning application in Grammar in Written Discourse class so far this semester can be considered successful for both students and lecturer. Some of the lesson learned and successes of the application can be discussed as follows:

1) Students are satisfied with learning process both in classroom meeting or during online activity. Students reported better understanding and the possibility for lesson review at home at their own learning pace.

2) Students are also excited to be using technology in the learning process. They reported feeling excited to come to class knowing that there will be an online interactive quiz through Kahoot! and excited to learn at home knowing that they will use Google Classroom and Quizziz and also will be taken do many different learning resources.

3) Students like to use of Google Classroom because the interface is userfriendly. It also keeps their lesson, materials and is a platform for them to discuss with peers and lecturers

4) Students like Quizziz because online assessment becomes easy. They like it when it is placed at the end of their learning process so they get to evaluate themselves based on their online assessment too. 
5) Students love Kahoot! in class. Students always like game and competition. What's more interesting is when the scoring is presented and they can race to win and at the same time assess how far their understanding have develop.

6) All students love the three online platform for the possibility to access it from multiple gadget: Laptop, desktop computer, tablet and mobile phones.

7) Lecturer as the designer and facilitator or Blended Learning must allocate time to plan and to prepare the blending of learning. The time must also be given for try-outs to make sure the product is effective and efficient.

8) More activities need to be developed to blend the learning even further. Therefore, we can move away from a mere technology integration to a proper blended learning.

9) Blended Learning proven to be beneficial for independent and autonomous learning especially during times when classroom activities are not possible. In Grammar in Written Discourse case, it was deemed helpful during Ambon Earthquake and during the time when the lecturer was away for 10 days on teaching trip with the university.

10) The pressure of maintaining blended learning: facilitating, assessing, teaching and monitoring, can be strenuous workload addition on top of the many responsibility that a lecturer already have. However, this strenuous workload can happen only when the preparation and planning were not conducted adequately. This workload mostly happens when you first develop the blended learning. Once you have done it, the next time may get easier.

\section{Conclusion And Recommendation}

Therefore, we can conclude that blended learning added a layer of interesting and exciting learning experience that benefit both students and lecturer. The students have the possibility to learn more even outside of classroom in the comfort of their home or in their own learning pace. Lecturer felt accomplished because the learning touched more students and received with better retention. Despite the fact that internet connectivity and access in Ambon are still poor, we can to certain extend introduce and help build a new mindset for our future students and introduce them to a healthier and more productive internet use habit.

This paper would like to end by giving some recommendation to the readers or to other educator who wants to apply or to develop this model.

1. Explore the use of the online platforms mentioned in this paper. Try to use it in your class. Designed your own take on it. The platforms are versatile and can be tailored to suit your and your students teaching and learning needs.

2. Explore new platforms, apps or strategy or models. Technology evolves very fast and as users, it is only fair for us to make sure we are in the loop and open to new discoveries and experience.

3. University has been boasting talks on e-learning, flipped learning and blended learning however, it has yet to provide better internet connection for the students. This is unfair to the students. We cannot expect the 4.0 teaching and 
learning to happen in the university when university itself is not willing to invest on a better facilities and infrastructure.

With new mindset, new healthy technology use habit, better facilities and infrastructure, we may be able to leverage the use of technology to serve the best for our teaching and learning experience. On the long run, it will help to create better graduates and more qualified young individuals venturing out to the community. (END)

\section{Bibliography}

Expat, I. (2019, March 13). Education 4.0: The Future Face of Education. Retrieved from Indonesian Expat: https://indonesiaexpat.biz/education-2/education-4-0-the-future-faceof-education/

FKIP-UNPATTI. (2018, July 27). Sosialisasi Program Penugasan Dosen di Sekolah (PDS) Dengan Sekolah Mitra. Retrieved from FKIPUNPATTI: http://fkip.unpatti.ac.id/sosialisasi-program-penugasandosen-di-sekolah-pds-dengan-sekolah-mitra/

Jisc. (2019, April 12). Preparing for Education 4.0. Retrieved from THE - Times High Education:

https://www.timeshighereducation.com/hub/jisc/p/preparingeducation-40\#survey-answer

Jonson, J. (2014, January 20). Blended Learning and Technology Integration. Retrieved September 21, 2019, from YouTube-JenJonson: https://www.youtube.com/watch?v=KD8AUfGsCKg

Karnad, A. (2014). Trends in Educational Tehnologies. London, UK: LSE EPrints.

Marr, B. (2016, April 5). Why Everyone Must Get Ready For The 4th Industrial Revolution. Retrieved from Forbes Website: https://www.forbes.com/sites/bernardmarr/2016/04/05/whyeveryone-must-get-ready-for-4th-industrialrevolution/\#1577fa863f90

Prihadi, S. D. (2017, February 11). Alasan Tarif Telkomsel di Indonesia Timur Mahal. Retrieved from CNN Indonesia: https://www.cnnindonesia.com/teknologi/20170210121605-213192595/alasan-tarif-telkomsel-di-indonesia-timur-mahal

Rahman, A. F. (2019, Mei 12). Telkomsel Perkuat Jaringan Internet Selama Ramadhan. Retrieved from DetikInet: https://inet.detik.com/telecommunication/d-4546200/telkomselperkuat-jaringan-internet-selama-ramadhan 
Rijoly, H. M. (2017). Are We There Yet? Assessing the Readiness of English Department, FKIP-Unpatti for E-Learning and Technology Enhanced Language Learning/Teaching. Proceedings of the International Conference on English Language Teaching (ICONELT 2017). 145, pp. 251 - 255. Atlantis Press. doi:https://doi.org/10.2991/iconelt17.2018 .53

Rijoly, H. M., \& Tuhumury, M. (2019, Agustus). Instagram Sebagai Alat Penilaian Ketrampilan Berbicara dan Strategi Peningkatan Keterlibatan Peserta Didik dalam Pembelajaran Bahasa Inggris di Kelas 7.1 SMP N 6 Ambon. Tahuri, 16(2), 22-34.

Safira, N. (2019, April 30). Dampak Penggunaan Gadget Pada Generasi Z. Retrieved from Kompasiana: https://www.kompasiana.com/nandasafirakml/5cc838c8cc52834c60 5aff23/dampak-penggunaan-gadget-pada-generasi-z?page=all

Schwab, K. (2016, January 14). The Fourth Industrial Revolution: what it means, how to respond. Retrieved from World Economic Forum: https://www.weforum.org/agenda/2016/01/the-fourth-industrialrevolution-what-it-means-and-how-to-respond/

Shively, K. (2017). Reflections from the Field: Creating an Elementary Living Learning Makerspace. Learning Communities Research and Practice, 5(1). Retrieved from https://www.researchgate.net/publication/328513105_Reflections_fr om_the_Field_Creating_an_Elementary_Living_Learning_Makerspa ce

Teach Thought Staff. (2018, December 2). The Definition of Blended Learning. Retrieved from Teach Thought: https://www.teachthought.com/learning/the-definition-of-blendedlearning/

Trisna, A. (2019, September 3). Bahaya Gadget Bagi Anak. Retrieved from The Asian Parent.Com: https://id.theasianparent.com/bahaya-gadget-bagianak

UNESCO. (2018). A Global Framework of Reference on Digital Literacy Skills for Indicator 4.4.2. Montreal, Canada: UNESCO Open Access Repository. 